\begin{tabular}{cr}
\hline Journal of Mathematics Science and Education \\
e-ISSN: $2623-2383.2018$, VOL. 1, NO. 1, 102-117 \\
DPENACCES
\end{tabular}$\quad \begin{array}{r}\text { DOI: https://doi.org/10.31540/jmse.v1i1.167 } \\
\hline\end{array}$

\title{
KESALAHAN MAHASISWA CALON GURU SD DALAM MENYELESAIKAN SOAL PEMECAHAN MASALAH MATEMATIKA
}

Fitri Apriani

STKIP Muhammadiyah Bangka Belitung, Indonesia

\begin{abstract}
ABSTRAK
Penelitian ini adalah penelitian deskriptif kualitatif yang bertujuan untuk mendskripsikan kesalahan mahasiswa dalam menyelesaikan soal pemecahan masalah matematika. Subjek penelitian adalah mahasisswa semester 7 Program studi PGSD STKIP Muhammadiyah Bangka Belitung yang mengambil mata kuliah Pemecehan Masalah Matematika dengan sampel satu kelas yang dipilih secara acak. Terdapat 45 mahasiswa dalam satu kelas. Data dikumpulkan melalui tes tertulis, dokumentasi, dan wawancara. Tes yang digunakan dalam penelitian ini adalah tes tertulis bentuk uraian. Data dianalisis dengan reduksi data, coding data, dan simpulan. Hasil penelitian menunjukkan Sebanyak 13 mahasiswa mengalami kesalahan dalam memahami masalah, 17 mahasiswa mengalami kesalahan dalam merencanakan penyelesaian, 4 mahasiswa mengalamai kesalahan dalam melaksanakan rencana, dan 8 mahasiswa mengalami kesalahan dalam tahap memriksa kembali proses dan hasil.
\end{abstract}

\section{PROSPECTIVE STUDENT TEACHERS SD ERROR IN RESOLVING THE MATTER OF SOLVING MATH PROBLEMS}

ABSTRACT

This research was qualitative descriptive research that aimed to describe errors made by university students in solving Mathematic problems. The subject of this research were seventh semester students of Primary School Education Study Program of STKIP Muhammadiyah Bangka Belitung that were taking Mathematic Problem Solving subject with the sample of one class students taken randomly. There were 45 students in one class. Data collected through a written test, documentation, and interviews. The tests usedin this research was essay written test. Data were analyzed with the reduction of data, coding data, and conclusions. Based on the result of the research, it was found that there were 13 students made error in understanding the problem, 17 students made error in planning the problem solving, 4 students made error in implementing the plan, and 8 students made error in revising the process and the result. 
\begin{tabular}{rr}
\hline Journal of Mathematics Science and Education \\
e-ISSN: 2623-2383. 2018, VOL. 1, NO. 1, 102-117 \\
DPENACCES
\end{tabular}$\quad \begin{array}{r}\text { DOIttps://doi.org/10.31540/jmse.v1i1.167 } \\
\hline\end{array}$

KEYWORDS

Kesalahan, Pemecahan Masalah, Matematika

Error, Problem Solving, Mathematics
ARTICLE HISTORY

Received 24 November 2018

Revised 28 December 2018

Accepted 5 December 2018

CORRESPONDENCE Fitri Apriani@fitri.apriani@stkipmbb.ac.id

\section{PENDAHULUAN}

Matematika adalah salah satu mata pelajaran pokok yang di ajarkan pada setiap jenjang pendidikan. Diungkapkan oleh Wahyudi dan Budiono (2012) bahwa matematika adalah salah satu ilmu dasar yang harus dikuasai olehsiswa sekolah karena matematika tidak dapat dipisahkan dari kehidupan manusia seharihari.Hal yang paling penting dalam matematika adalah pemecahan masalahnya. Sebagaimana yang diungkapkan oleh Lester bahwa "Problem solving is the heart of mathematics" (Sugiman dan Kusumah, 2010). Hal yang sama juga diungkapkan oleh Roebyanto dan Harmini (2017) bahwa proses pemecahan masalah merupakan bagian terpenting dan tidak dapat dipisahkan dalam proses pembelajaran matematika. Pemecahan masalah juga merupakan salah satu dari lima tujuan pembelajaran matematika. Menurut NCTM (2000), ada lima tujuan yang menjadi fokus dalam kemampuan belajar matematika, yaitu 1) kemampuan pemecahan masalah, 2) kemampuan penalaran dan pembuktian, 3) kemampuan koneksi, 4) kemampuan komunikasi, dan 5) kemampuan representasi. Dari pendapat diatas, terlihat bahwa pemecahan masalah merupakan hal yang paling penting dalam pembelajaran matematika.

Pemecahan masalahtelah ditempatkan sebagai titik awal dari pembelajaran matematika oleh beberapa negara seperti Amerika dan Singapura. Amerika Serikat dan Singapura pada jenjang sekolah dasar dan sekolah menengah telah menempatkan kemampuan pemecahan masalah menjadi pusat dalam pengajaran matematika (Ruseffendi, 2006). Pemecahan masalah dalammatematika adalah aktivitas yang digunakan untukmencari penyelesaian dari masalahmatematika yang dihadapi oleh peserta didik denganmenggunakan semua pengetahuanmatematika yang dimiliki (Widodo dan Sujadi, 2015). Menurut 
Wahyudi dan Anugraheni(2017), ada dua jenis soal pemecahan masalah yaitu soal rutin dan soal non rutin. Soal rutin adalah aplikasi prosedurmatematika yang mirip dengan hal yang barudipelajari. Sedangkan dalam masalah tidak rutin, untuksampai pada prosedur yang benar diperlukan pemikiranyang lebih mendalam. Namun persoalan yang muncul dilapangan adalah tidak semuapembelajaran matematika menggunakan masalahmatematika tidak rutin karena soal-soal rutin banyak diberikan dalam pembelajaran (Wahyudi dan Budiono, 2012).

Polya menyatakan bahwa langkah-langkah dalam pemecahan masalah matematika adalah (1) memahami masalah, (2) merencanakan penyelesaian, (3) melaksanakan perencanaan, dan(4) memeriksa kembali proses dan hasil (Roebyanto dan Harmini, 2007). Gagne menyatakan bahwa terdapat lima tahap pemecahan masalah yaitu: (1) Penyajian masalah; (2) menyatakan masalah dalam bentuk operasional; (3) penyusunan prosedur kerja yang baik yang diperkirakan dapat dipergunakan dalam memecahkan masalah itu; (4) mengetes hipotesis dan melakukan kerja untuk memperoleh hasilnya; (5) memeriksa kembali (mengecek) apakah hasil yang diperoleh itu benar (Wahyudi dan Anugraheni, 2017).Dewey menyatakan bahwa terdapat lima tahap pemecahan masalah yaitu: (1) tahu bahwa ada masalah, (2) mengenali masalah, (3) menggunakanpengalaman yang lalu, (4) menguji secara berturut-turut hipotesa atau kemungkinan-kemungkinan penyelesaian, (5) mengevaluasi penyelesaian dan menarik kesimpulan berdasarkan bukti- bukti yang ada (Wahyudi dan Anugraheni, 2017). Dari beberapa pendapat diatas, langkah-langkah pemecahan masalah sebenarnya bermuara pada langkah-langkah pemecahan masalah menurut Polya.

Pembelajaran pemecahan masalah dalam matematika ada baiknya diajarkan mulai dari pendidikan yang paling dasar yaitu SD. Selain diarahkan pada peningkatan kemampuan siswa dalam berhitung, pembelajaran matematika di sekolah dasar juga harus diarahkan kepada peningkatan kemampuan siswa dalam pemecahan masalah (Ningsih, 2018). Namun, menurut Arrahim dan Amalia (2018), rendahnya kemampuan pemecahan masalah merupakan masalah yang sering ditemukan dalam pembelajaran matematika, dikarenakan di dalam soal https://ojs.stkippgri-lubuklinggau.ac.id/index.php/JMSE 
yang diberikan, siswa belum bisa mengidentifikasi masalahnya. Selain itu, siswa juga dalam menjawab soal tidak sesuai dengan langkah-langkah yang benar. Rendahnya kemampuan pemecahan masalah pada mata pelajaran matematika membuat siswa kesulitan dalam menyelesaikan suatu masalah persoalan matematika. Namun kenyataannya, rangkaian kegiatan dalam pembelajaran matematika selama ini dimulai dengan guru menyajikan masalah, selanjutnya guru melakukan demonstrasi bagaimana cara penyelesaian masalah tersebut, dan pada akhirnya siswa diminta untuk menyelesaikan latihan soal yang diberikan guru (Eviliyanida, 2010).

Sebenarnya, untuk membiasakan siswa SD dalam kemampuan pemecahan masalah matematika, setidaknya guru harus sebagai fasilitator. Karena melalui proses pemcahan masalah tersebut dapat mengembangkan rasa percaya diri siswasehingga siswa siap dalam menghadapi tantangan dalam kehidupan seharihari karena tidaklah cukup hanya melatih proses berpikir secara matematis saja. Pada Program Studi Pendidikan Guru Sekolah Dasar (PGSD) terdapat Mata Kuliah Pemecahan Masalah Matematika. Tujuan Mata Kuliah ini agar mahasiswa mampu memahami Pembelajaran pemecahan masalah matematika dalam berbagai topik.

Hasil tes pertama pada mata kuliah ini, $80 \%$ mahasiswa tidak dapat menjawab pertanyaan dengan benar. Dari 80\% mahasiswa ini, 31\% mahasiswa salah dalam perhitungan dan $49 \%$ mahasiswa tidak mengerti maksud soal karena mereka tidak terbiasa dalam mengerjakan soal pemecahan masalah matematika. Selanjutnya, dari $20 \%$ mahasiswa menjawab pertanyaan dengan benar, hanya $7 \%$ mahasiswa yang menjawab pertanyaan dengan jalan ditanya, diketahui, dan penyelesaian sedangkan 13\% mahasiswa menjawab pertanyaan langsung. Oleh karena itu, untuk mengatasi kesulitan mahasiswa tersebut, diberikan penjelasan mengenai langkah-langkah penyelesaian pemecahan masalah matematika. Setelah itu dilakukan analisis atau identifikasi kesalahan yang dilakukan dalam menyelesaikan soal pada saat Ujian Tengah Semester (UTS) berdasarkan langkahlangkah yang telah diberikan, agar dapat diperbaiki hasil belajar mahasiswa setelah UTS dilakukan. 
Berdasarkan langkah-langkah Polya, maka analisis kesalahan dalam menyelesaikan masalah matematika dalam penelitian ini adalah.

1. Kesalahan memahami masalah, dengan indikator kesalahan yaitu: 1). mahasiswa tidak dapat menyebutkan apa yang diketahui pada soal, dan 2). mahasiswa tidak dapat menyebutkan apa ditanyakan oleh soal.

2. Kesalahan merencanakan penyelesaian, dengan indikator kesalahan yaitu: 1). Mahasiswa tidak menggunakan semua informasi dalam soal, dan 2). Mahasiswa tidak memilih strategi yang tepat untuk menyelesaikan masalah.

3. Kesalahan melaksanakan perencanaan, dengan indikator kesalahan yaitu: 1). Mahasiswa tidak menggunakan langkah-langkah atau prosedur dengan benar, dan 2). Mahasiswa tidak tepat dalam menjawab soal.

4. Kesalahan memeriksa kembali proses dan hasil, dengan indikator kesalahan yaitu: 1). Mahasiswa tidak memeriksa kecocokan jawaban terhadap masalah pada soal, dan 2). Mahasiswa tidak mencari alternatif jawaban atau strategi lain dalam menjawab permasalahan.

Menyangkut strategi untuk menyelesaikan masalah, Wahyudi dan Anugraheni (2017) antaralain menyebutkan beberapa strategi pemecahan masalah, yaitu: (1) Act it Out, (2) Membuat gambaratau diagram, (3) Mencari pola, (4) Membuat tabel, (5) Memperhatikan semuakemungkinan secara sistematis, (6) Tebak dan periksa, (7) Strategi bekerja mundur, (8) Mengidentifikasi informasi yang diinginkan, diberikan, dan butuhkan, (9) Menulis kalimat terbuka, (10) Menyelesaikan masalah yang lebih sederhana atau serupa, dan (11) Mengubah pandangan.

Menurut Lidinilah (2012),jika seseorang mempunyai kemampuan pemecahan masalah yang diberikan dengan cara memilih stretegi yang baik, maka seseorang dianggap sebagai pemecah masalah yang baik. Sedangkan jika mahasiswa melakukan indikator kesalahan yang diberikan dalam tahap-tahap pemecahan masalah matematika, maka seseorang tersebut telah melakukan kesalahan dalam pemecahan masalah matematika (Widodo dan Sujadi, 2015).

Sukirman menjelaskan ada beberapa jenis kesalahan dalam mengerjakan soal matematika yaitu meliputi: (1) kesalahan penggunaan konsep dalam materi, (2) https://ojs.stkippgri-lubuklinggau.ac.id/index.php/JMSE 


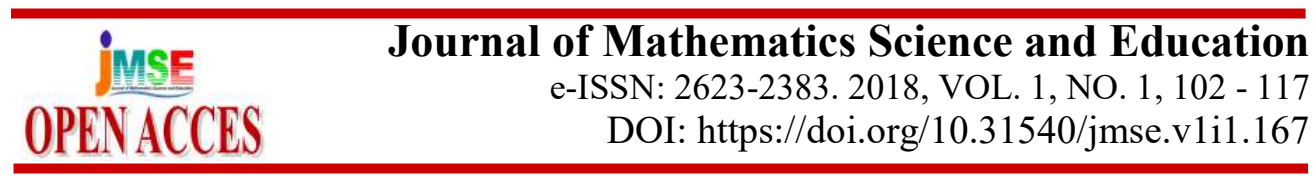

kesalahan prinsip, yaitu kesalahan yang berkaitan dengan hubungan dua atau lebih objek, (3) kesalahan operasi, yaitu kesalahan dalam melakukan perhitungan (Amir, 2015). Abidin (2012) menyatakan bahwa ada empat jeniskesalahan yaitu (1) kesalahan konsep yaitu ketidakmampuan dalam menentukan rumus atau teorema apa yang baik digunakan untuk menyelesaikan masalah, (2) kesalahan prinsip yaitu kesalahan dalam menuliskan rumus, (3) kesalahan teknis yaitu kesalahan karena ketidakmampuan melakukan perhitungan dengan tepat, dan (4) kesalahan algoritma/prosedur yaitu kesalahan karena ketidakmampuan menjalankan langkah-langkah dalam menyelesaikan masalah. Widodo dan Sujadi (2015) menyatakan bahwa jenis kesalahan terbagi menjadi tiga yaitu kesalahan konsep, kesalahan prinsip dankesalahan operasi. Kesalahan konsep adalahkesalahan pemahaman terhadap konsepyang terkait dengan materi. Kesalahan prinsip adalah kesalahanmemahami dan menerapkan prinsip yang ada dalam soal. Dari ketiga pendapat di atas, dapat ditarik kesimpulan untuk penelitian ini yang diambil dari indikator kesalahan berdasarkan langkah-langkah Polya yang dijabarkan diatas, dapat diidentifikasi apa saja kesalahan yang dilakukan oleh mahasiswa. Sebagaimana dalam penelitian ini, kesalahan yang akan dilihat adalah kesalahan konsep, kesalahan prinsip dan kesalahan operasi. Dimana kesalahan konsep adalah mahasiswa tidak mampu menentukan masalah dan konsep yang akan digunakan. Kesalahan prinsip adalah dimana mahasiswa tidak tau strategi dan rumus apa yang harus digunakan untuk menyelesaikan soal. Dan kesalahan operasi adalah dimana mahasiswa salah dalam menghitung.

Analisis kesalahan akan dilakukan secara mendalam agar kesalahankesalahan mahasiswa dapat diminimalisir sehingga hasil belajar mahasiswa dapat meningkat. Sehingga saat mahasiswa terjun ke lapangan sebagai seorang guru, mahasiswa dapat memberikan pemecahan masalah pada siswa Selanjutnya diperlukan identifikasi faktor-faktor yang menyebabkan terjadinya kesalahan tersebut.Karena menurut Roebyanto dan Harmini (2017) bahwa peran guru dalam pembelajaran pemecahan masalah ada empat level yaitu (1) level pengenalan, pada level ini guru berperan dalam mengenalkan langkah-langkah penyelesaian masalah menurut Polya, (2) level pemula, pada level ini guru bertindak sebagai https://ojs.stkippgri-lubuklinggau.ac.id/index.php/JMSE 
pembimbing dengan menawarkan alternatif strategi saat siswa mengalami kesulitan, (3) level penggemar, pada level ini, peran guru adalah sebagai penyedia permasalahan yang meantang yang bertujuan untuk membantu siswa dalam mengumpulkan pengalaman dalam penyelesaian masalah matematika, dan (4) level ahli, pada level ini guru hanya memancing siswa dengan pertanyaan agar siswa berpikir apakah strategi atau jawaban yang mereka peroleh sudah benar. Untuk menjalankan peran tersebut, calon guru harus berlatih dalam menyelesaikan soal pemecahan masalah matematika terlbih dahulu. Pada mata kuliah Pemecahan Masalah Matematika ini diharapkan mahasiswa mampu membiasakan diri dan mampu menguasai penyelesaian masalah matematika dikarenakan pemecahan masalah matematika baik di SD. Karena pada dasarnya pembelajaran matematika di SD harus diarahkan pada kemampuan pemecahan masalan. Berdasarkan hal tersebut maka tujuan penelitian ini adalah untuk mendskripsikan kesalahan mahasiswa dalam menyelesaikan soal pemecahan masalah matematika.

\section{METODE}

Penelitian ini adalah penelitian deskriptif kualitatif yang bertujuan untuk mendskripsikan kesalahan mahasiswa dalam menyelesaikan soal pemecahan masalah matematika. Penelitian kualitatif adalah penelitian yang digunakan untuk meneliti pada kondisi obyek yang alamiah, dimana peneliti adalah sebagai instrumen kunci, teknik pengumpulan data dilakukan dengan triangulasi (gabungan), analisis data bersifat induktif, dan hasil penelitian lebih menekankan makna daripada generalisasi (Sugiyono, 2010).

Subjek penelitian adalah mahasisswa semester 7 Program studi PGSD STKIP Muhammadiyah Bangka Belitung yang mengambil mata kuliah Pemecehan Masalah Matematika di SD. Sedangkan sampel penelitian ini adalah satu kelas saja yang dipilih secara acak yaitu sebanyak 45 mahasiswa dikarenakan pada penelitian deskriftif kualitatif ini banyaknya subjek penelitian diserahkan sepenuhnnya kepada peneliti. Dalam penelitian ini, peneliti terjun langsung untuk mendapatkan hasil yang lebih mendalam tentang kesalahan mahasiswa dalam mengerjakan soal pemecahan masalah matematika sehingga diharapkan data yang https://ojs.stkippgri-lubuklinggau.ac.id/index.php/JMSE 
dikumpulkan lebih mendalam, kredibel, dan lebih bermakna sehingga tujuan penelitian tercapai.

Pengumpulan data dilakukan dengan cara tes tertulis, semua dokumen hasil mahasiswa dalam menyelesaikan tes tertulis, dan wawancara tak berstruktur dengan pedoman wawancara yang telah disiapkan serta triangulasi. Tes tertulis yang digunakan adalah tes tertulis bentuk uraian untuk memperoleh data kesalahan mahasiswa dalam menjawab soal pemecahan masalah berdasarkan langkah penyelesaian pemecahan masalah menurut Polya.Salah satu kelebihan dari bentuk tes uraian adalah dapat diketahui sejauh mana mahasiswa mendalami suatu masalah yang diteskan (Arikunto, 2006). Sehingga diharapkan data yang diperoleh bisa menggambarkan langkah-langkah penyelesaian Polya. Data diperoleh dari jawaban mahasiswa dalam mengerjakan tes uraian tersebut kemudian mahasiswa diwawancara untuk mengetahui faktor penyebab kesalahan yang dibuat mahasiswa dalam menyelesaikan tes.Sedangkan triangulasi adalah pengecekan data kepada sumber yang sama dengan teknik berbeda. Dalam penelitian ini yaitu tes tertulis dan wawancara.

Analisis data yaitu dengan cara (1) reduksi data, pada tahap ini dilakukan kegiatan mengoreksi hasil pekerjaan mahasiswa, hasil jawaban siswa dikoreksi berdasarkan langkah-langkah polya dan jenis-jenis kesalahan yang telah diberikan pada pendahuluan, sehingga data dapat diklasifikasikan langsung berdasarkan kesalahan yang dilakukan oleh mahasiswa, (2) coding data, pada tahap ini, hasil pekerjaan mahasiswa yang menjadi subjek penelitian dikelompokkan berdasarkan kesalahan yang dilakukan. Hal ini digunakan sebagai bahan untuk wawancara, wawancara yang dilakukan adalah wawancara tak terstruktur. Pedoman wawancara disediakan berdasarkan langkah-langkah polya tetapi tetap melihat hasil jawaban mahasiswa dalam lembar jawaban. Sehingga bahasan wawancara hanya mencakup fokus jawaban mahasiswa saja, dan (3) simpulan, pada tahap ini, hasil wawancara dan tes uraian singkat disederhanakan agar data rapi, sehingga tidak menyulitkan peneliti dalam menarik kesimpulan dan menganalisis data. Kemudian dilakukan analisis data dengan deskriptif kualitatif. 


\begin{tabular}{rr}
\hline Journal of Mathematics Science and Education \\
e-ISSN: 2623-2383. 2018, VOL. 1, NO. 1, 102-117 \\
OPENACCES
\end{tabular}$\quad$\begin{aligned} DOI: https://doi.org/10.31540/jmse.v1i1.167 \\
\hline\end{aligned}

Analisis data deskriptif kualitatif juga menggunakan data kuantitatif untuk melihat persentase jenis kesalahan tiap langkah-langkah penyelesaian pemecahan masalah matematika menurut Polya pada soal yang diberikan.

Klasifikasi kesalahan (P) yang dilakukan oleh mahasiswa dalam menyelesaikan pemecahan masalah matematika berdasarkan persentase yang didapat ditentukan sebagai berikut:

$$
\begin{array}{ll}
0 \% \leq P<20 \% & : \text { Sangat Rendah } \\
20 \%<P \leq 40 \% & : \text { Rendah } \\
40 \%<P \leq 60 \% & : \text { Cukup Tinggi } \\
60 \%<P \leq 80 \% & : \text { Tinggi } \\
80 \%<P \leq 100 \% & : \text { Sangat Tinggi }
\end{array}
$$

(Widodo dan Sujadi, 2015)

\section{HASIL DAN PEMBAHASAN}

Penelitian dilakukan dengan melibatkan mahasiswa semester 7 PGSD STKIP Muhammadiyah Bangka Belitung. Subjek penelitian adalah mahasiswa kelas A sebanyak 45 mahasiswa. Hasil dari kesalahan mahasiswa dalam menyelesaikan soal pemecahan masalah matematika berdasarkan langkah-langkah penyelesaian Polya adalah sebagai berikut:

Tabel 1. Klasifikasi Kesalahan Mahasiswa

\begin{tabular}{lll}
\hline Tahap Penyelesaian Polya & $\begin{array}{l}\text { Persentase } \\
\text { Kesalahan }\end{array}$ & Klasifikasi \\
\hline Memahami Masalah & 28,9 & Rendah \\
Merencanakan Penyelesaian & 53,1 & Cukup Tinggi \\
Melaksanakan Perencanaan & 17,4 & Sangat Rendah \\
Memeriksa Kembali Proses dan Hasil & 42,1 & Cukup Tinggi \\
\hline
\end{tabular}




\begin{tabular}{rr}
\hline Journal of Mathematics Science and Education \\
e-ISSN: $2623-2383.2018$, VOL. 1, NO. 1, 102-117 \\
OPENACCES
\end{tabular}$\quad \begin{array}{r}\text { DOI: https://doi.org/10.31540/jmse.v1i1.167 } \\
\hline\end{array}$

\section{Kesalahan Memahami Masalah}

Untuk mengetahui kesalahan pada tahap ini, dilihat dari indikator kesalahan pada langkah memahami masalah adalah mahasiswa tidak dapat menyebutkan apa yang diketahui pada soal dan mahasiswa tidak dapat menyebutkan apa yang ditanyakan pada soal. Menurut Widodo dan Sujadi (2015), mahasiswa yang melakukan kesalahan pada tahapan memahami masalah dapat mengakibatkan ketidakmampuan mahasiswa menyelesaikan masalah pada tahap berikutnya.

Pada soal yang diberikan, ada 4 mahasiswa yang salah dalam menentukan atau menuliskan apa yang diketahui dan ditanya oleh soal. Sedangkan ada 7 mahasiswa yang sama sekali tidak menuliskan apa yang diketahui dan ditanyakan soal. Hal ini dapat disimpulkan bahwa 11 mahasiswa tersebut belum memahami masalah yang diberikan pada soal. Karena mereka tidak paham dan tidak mengetahui apa yang yang dimaksud oleh soal sehingga menyebabkan mereka salah maupun tidak menuliskan sama sekali apa yang diketahui dan ditanya pada soal yang diberikan. Kesalahan tahap pertama ini dikategorikan kesalahn konsep.

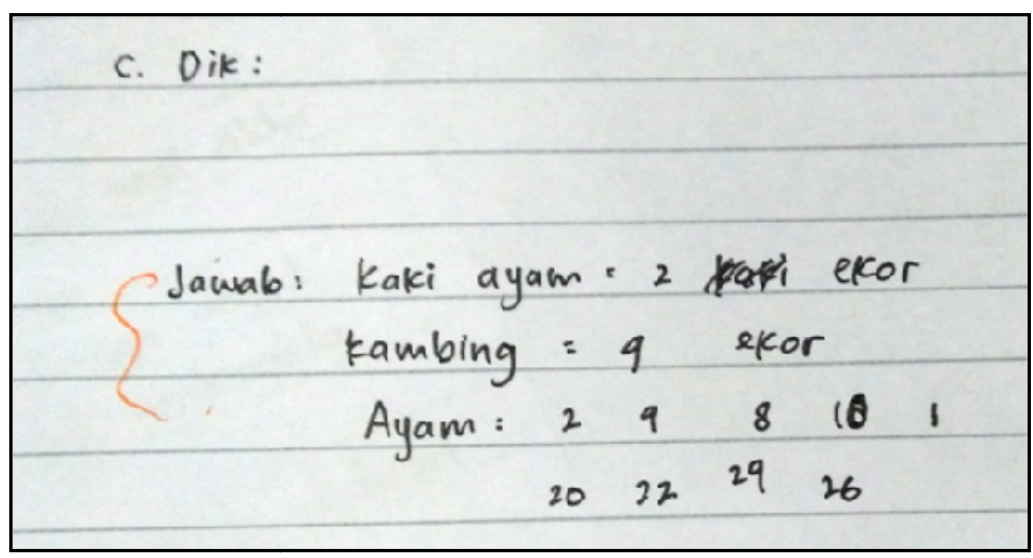

\section{Gambar 1. Salah Satu Jawaban Mahasiswa yang Tidak Memahami Masalah}

Selanjutnya, ada 2 mahasiswa yang tidak menuliskan apa yang diketahui dan apa yang ditanya oleh soal tetapi mereka mampu menjawab permasalahan dengan tepat dan benar. 

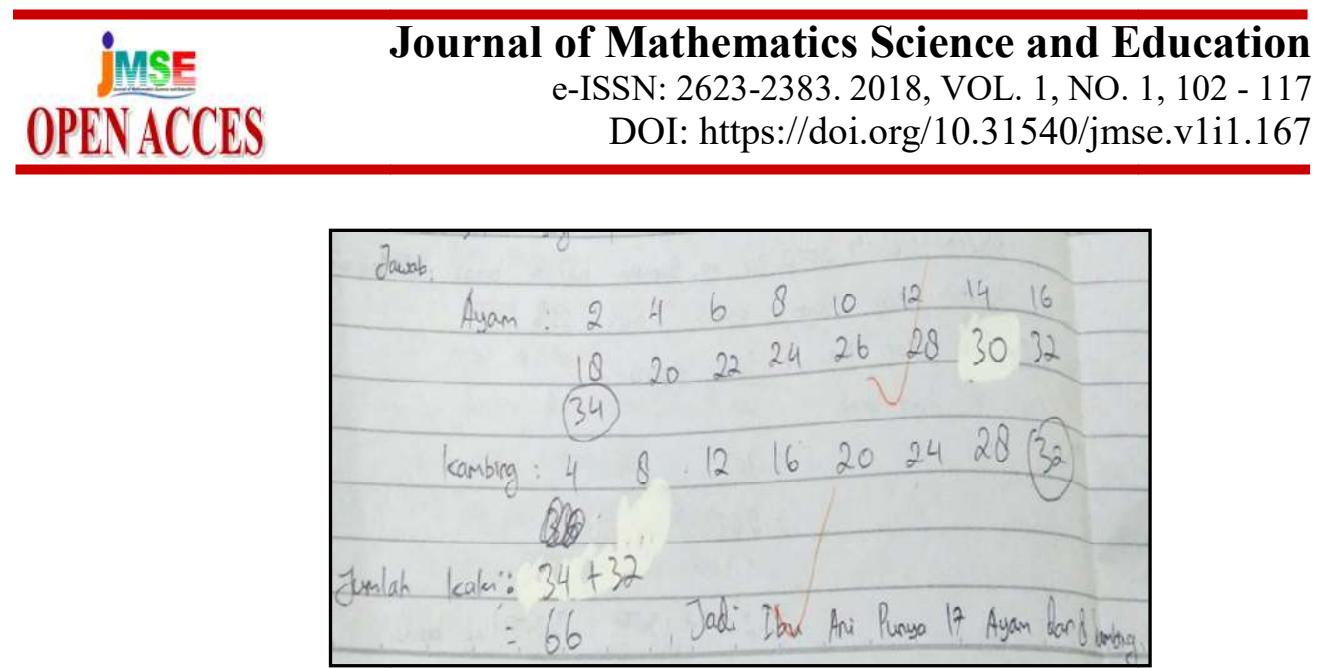

\section{Gambar 2. Salah Satu Jawaban Mahasiswa yang Menjawab Langsung}

Kedua mahasiswa tersebut dikatakan telah memahami masalah karena mampu menyelsaiakan permasalah dengan benar. Hal itu dilakukan karena mereka telah terbiasa dalam mengerjakan soal tanpa menulis apa yang diketahui dan ditanyakan soal.

Berdasarkan uraian diatas, banyak mahasiswa yang melakukan kesalahan pada tahap memahami masalah sebanyak 13 mahasiswa atau 28,9\% mahasiswa melakukan kesalahan. Jadi, klasifikasi kesalahan untuk tahap ini adalah rendah.

\section{Kesalahan Merencanakan Penyelesaian}

Untuk mengetahui kesalahan pada tahap ini, dilihat dari indikator kesalahan pada langkah merencanakan penyelesaian adalah mahasiswa tidak menggunakan semua informasi dalam soal dan mahasiswa tidak memilih strategi yang tepat untuk menyelesaikan masalah. Memilih strategi yang tepat untuk menjawab permasalahan dapat membantu mahasiswa menjawab soal dengan tepat dan benar.

Pada soal yang diberikan, sebanyak 11 mahasiswa yang tidak memahami masalah pada langkah pertama, juga tidak menjawab apapun pada tahap ini. Sedangkan 2 mahasiswa yang mampu menjawab soal dengan tepat dan benar yang dijelaskan pada tahap memahami masalah juga tidak memilih strategi yang telah diberikan.

Sebanyak 9 mahasiswa yang benar pada langkah pertama, namun untuk langkah kedua ini mereka tidak dapat memilih strategi dan menggunakan informasi yang tepat yang ada. Sehingga siswa tersebut tidak melanjutkan https://ojs.stkippgri-lubuklinggau.ac.id/index.php/JMSE 


\begin{tabular}{cr}
\hline JMSE & $\begin{array}{r}\text { Journal of Mathematics Science and Education } \\
\text { e-ISSN: 2623-2383. 2018, VOL. 1, NO. 1, 102 - 117 } \\
\text { OPENACCES }\end{array}$ \\
\hline
\end{tabular}

penyelesaian ke langkah ketiga yaitu melaksanakan perencanaan. Hal ini dikarenakan mereka bingung konsep apa yang harus digunakan dalam menyelesaiakan permasalahan tersebut dan strategi apa yang cocok digunakan untuk menyelesaikan soal. Sehingga mereka tidak dapat memilih strategi dan melanjutkan tahapan ketiga.

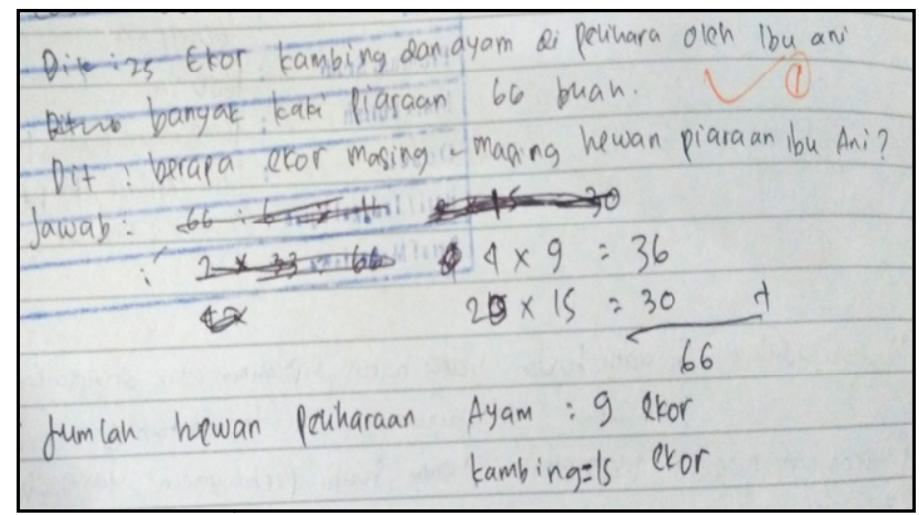

Gambar 3. Salah Satu Jawaban Mahasiswa Tidak Memilih Strategi

Selanjutnya ada 8 mahasiswa yang tidak menuliskan strategi apa yang mereka gunakan dalam menjawab soal tetapi tepat dan benar menjawab soal yang diberikan. Hal ini dikarenakan mereka kebingungan menentukan strategi namun mereka mengetahui langkah atau prosedur yang harus digunakan untuk menjawab permasalahan dalam soal tersebut. Kesalahan pada tahap kedua ini adalah kesalahan prinsip.

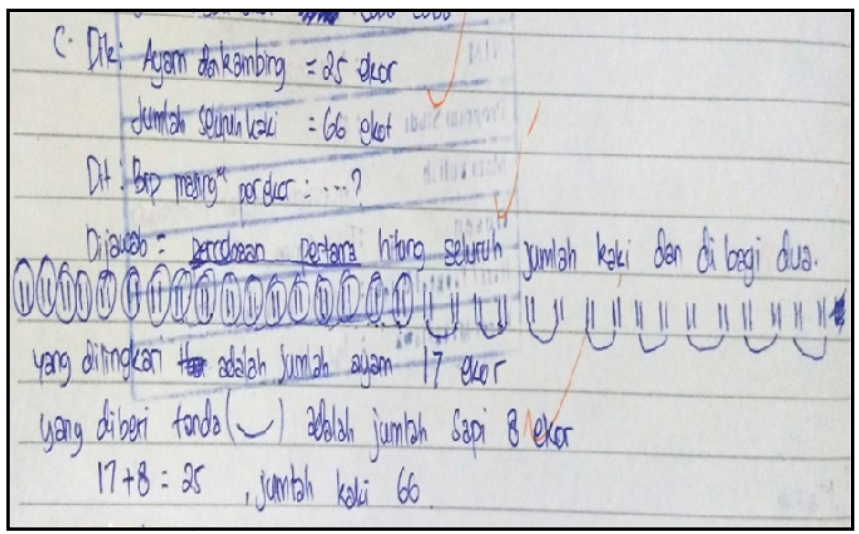

Gambar 4. Salah Satu Jawaban Mahasiswa yang Tidak Memilih Strategi tapi Benar

https://ojs.stkippgri-lubuklinggau.ac.id/index.php/JMSE 


\begin{tabular}{cr}
\hline Journal of Mathematics Science and Education \\
e-ISSN: $2623-2383.2018$, VOL. 1, NO. 1, 102-117 \\
DPENACCES
\end{tabular}$\quad \begin{array}{r}\text { DOI: https://doi.org/10.31540/jmse.v1i1.167 } \\
\hline\end{array}$

Berdasarkan uraian di atas, banyak mahasiswa mengalami kesalahan pada langkah merencanakan penyelesaian ada 17 mahasiswa atau 53,1\% mahasiswa melakukan kesalahan. Jadi, klasifikasi kesalahan untuk tahap ini adalah cukup tinggi.

\section{Kesalahan Melaksanakan Perencanaan}

Untuk mengetahui kesalahan pada tahap ini, dilihat dari indikator kesalahan dalam langkah melaksanakan perencanaan adalah mahasiswa tidak menggunakan langkah-langkah atau prosedur dengan benar dan mahasiswa tidak tepat dalam menjawab soal. Prosedur yang benar dan tingkat ketelitian mahasiswa dalam menghitung harus diperhatikan pada tahap ketiga ini. Karena kesalahan sedikit saja dalam perhitungan akan menyebabkan jawaban menjadi salah.

Pada soal yang diberikan, terdapat 4 mahasiswa yang melakukan kesalahan pada tahap ini. Keemapat mahasiswa tersebut salah dalam operasi hitung penjumlahan dan perkalian. Banyak yang hanya menjumlahkan kaki-kaki hewan peliharaan saja tanpa melihat berapa banyak hewannya. Jumlah kakiknya sudah pas, namun untuk jumlah hewan yang ada masih terdapat kekeliruan. Kesalahan pada tahap ketiga ini adalah kesalahan operasi ataupun sebaliknya.

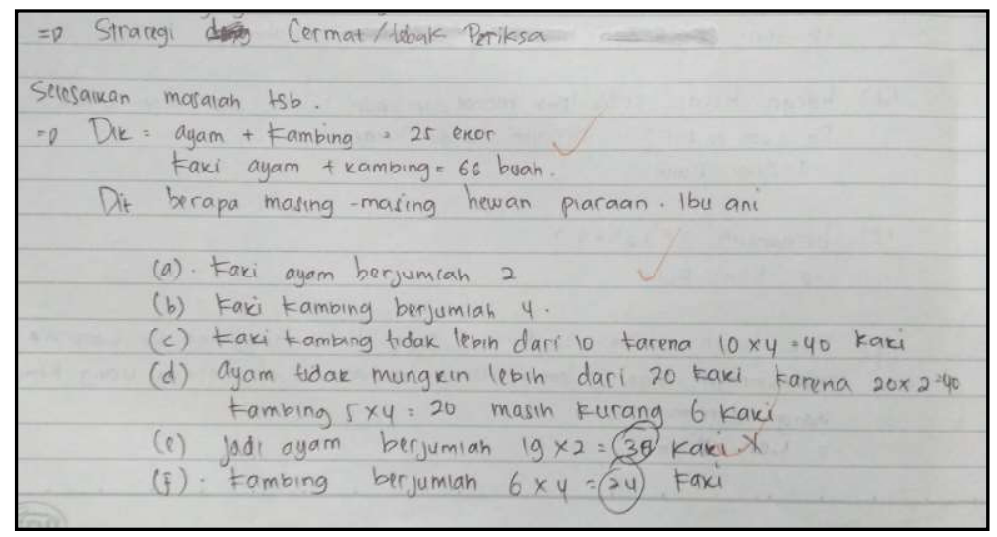

\section{Gambar 5. Salah Satu Jawaban Mahasiswa yang Salah Perhitungan}

Mahasiswa menyadari bahwa mereka kurang teliti dalam memperhatikan soal yang diberikan (permasalahan dalam soal). Sehingga ada informasi yang https://ojs.stkippgri-lubuklinggau.ac.id/index.php/JMSE 


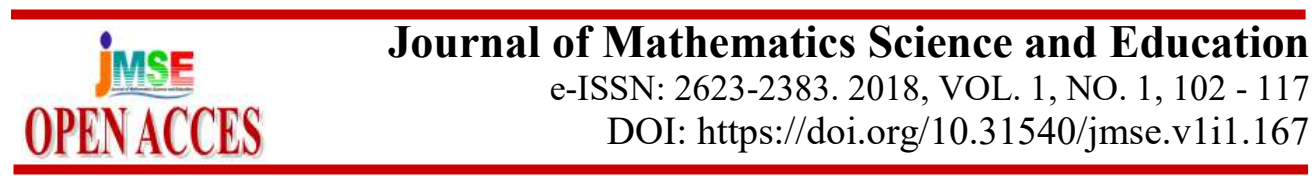

terlewatkan dalam soal yang mengakibatkan kesalahan dalam menjawab. Padalah prosedur dan strategi yang digunakan sudah tepat. Sehingga sebenarnya memungkinkan mahasiswa menjawab pertanyaan dari permasalahan yang ada dalam soal dengan tepat.

Berdasarkan uraian tersebut diatas, sebanyak 17,4 \% yang mengalami kesalahan. Jadi, klasifikasi kesalahan untuk tahap ini adalah sangat rendah.

\section{Kesalahan Memeriksa Kembali Proses dan Hasil}

Untuk mengetahui kesalahan pada tahap ini, dilihat dari indikator kesalahan pada tahap ini adalah mahasiswa tidak memeriksa kecocokan jawaban terhadap masalah di soal dan mahasiswa tidak mencari alternatif jawaban atau strategi lain dalam menjawab permasalahan. Tahap ini dimaksud agar mahasiswa dapat mengecek apakah jawaban yang telah diperoleh benar dan tepat. Atau juga memungkinkan ada strategi dan alternatif jawaban lain dalam permasalahan yang diberikan.

Pada soal yang diberikan, terdapat 8 mahasiswa dengan jawaban yang benar tetapi tidak melakukan pengecekan kembali terhadap hasil yang diperoleh. Hal ini dikarenakan sebagian dari mereka sudah puas dengan jawaban yang diperoleh sehingga mereka tidak melihat kembali jawaban yang diperoleh dan tidak melakukan strategi dan alternatif lain untuk menjawab pertanyaan tersebut.

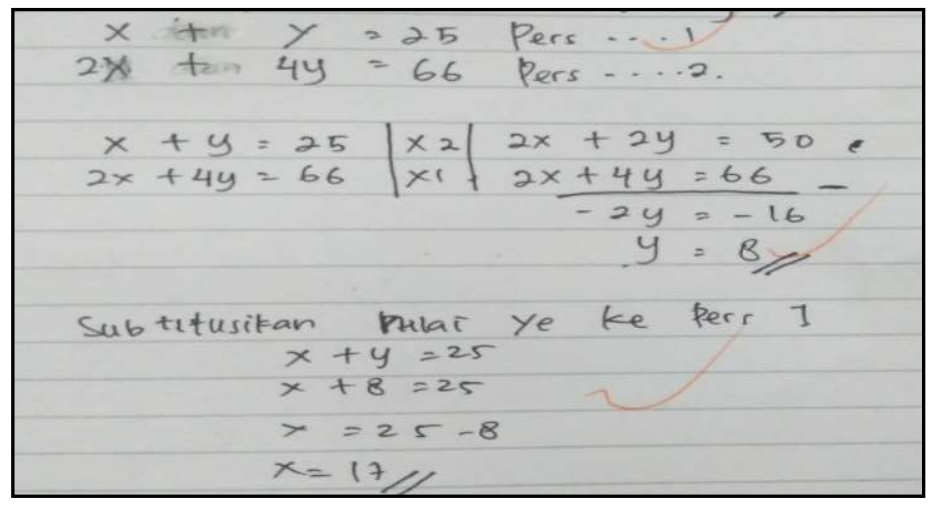

\section{Gambar 6. Salah Satu Jawaban Mahasiswa yang Tidak Melakukan}




\begin{tabular}{cr}
\hline Journal of Mathematics Science and Education \\
e-ISSN: $2623-2383.2018$, VOL. 1, NO. 1, 102-117 \\
DOI: https://doi.org/10.31540/jmse.v1i1.167
\end{tabular}

KESIMPULAN

Berdasarkan pembahasan diperoleh kesimpulan bahwa sebanyak 13 mahasiswa mengalami kesalahan dalam memahami masalah yang dapat dilihat dari mahasiswa tidak menulis apa yang diketahui dan ditanyakan pada lembar jawaban (kesalahan konsep), 17 mahasiswa mengalami kesalahan dalam merencanakan penyelesaian yang dapat dilihat dari mahasiswa tidak meluiskan strategi apa yang akan digunakan dalam menyelesaikan permasalahan (kesalahan prinsip), 4 mahasiswa mengalamai kesalahan dalam melaksanakan rencana dikarenakan mahasiswa salah dalam proses perhitungaan (kesalahan operasi), dan 8 mahasiswa mengalami kesalahan dalam tahap memriksa kembali proses dan hasil dilihat dari mahasiswa tidak mengecek kembali jawaban dan tidak memilih alternatif jawaban lain karena merreka sudah merasa puas dengan jawabannya.

\section{DAFTAR RUJUKAN}

Abidin, M. Z. (2012, Desember 8). Kesalahan Konseptual dan Prosedural Siswa dalam Belajar Aljabar. Diambil kembali dari www.masbied.com/2012/12/08/kesalahan-konseptual-dan-prosedural-siswadalam-belajar-aljabar/.

Amir, M. F. (2015). Analisis Kesalahan Mahasiswa PGSD Universitas Muhammadiyah Sidoarjo dalam Menyelesaikan Soal Pertidaksamaan Linear. Jurnal Edukasi , 131-145.

Arikunto, S. (2006). Prosedur Penelitian Pendekatan Praktek. Jakarta: Rineka Cipta.

Arrahim, A., \& Amalia, S. (2018). Penerapan Model Pembelajaran Kooperatif Tipe Team Assisted Individualization (TAI) untuk Meningkatkan Kemampuan Pemecahan Masalah pada Mata Pelajaran Matematika Kelas IV SD Negeri Wanasari 14 Cibitung-Bekasi. Pedagogik (Jurnal Pendidikan Sekolah Dasar), 6(1), 21-30.

Eviliyanida, E. (2010). Pemecahan Masalah Matematika. Jurnal Visipena, 1(2), $10-17$.

Lidinilah, D. A. (2012). Heuristik dalam Pemecahan Masalah Matematika dan Pembelajarannya di Sekolah Dasar. Dipetik Mei 25, 2018, dari file upi edu: http://file.upi.edu/Direktori/KD-TASIKMALAYA.

https://ojs.stkippgri-lubuklinggau.ac.id/index.php/JMSE 


\begin{tabular}{cr}
\hline Journal of Mathematics Science and Education \\
e-ISSN: 2623-2383. 2018, VOL. 1, NO. 1, 102-117 \\
OPENACCES
\end{tabular} $\begin{array}{r}\text { DOI: https://doi.org/10.31540/jmse.v1i1.167 } \\
\hline\end{array}$

National Council of Teachers of Mathematics (2000).Principles and Standars for School Mathematics. Reston, Va: NCTM.

Ningsih, S. D. (2018, Februari 4). Strategi Pembelajaran Pemecahan Masalah di Sekolah Dasar. Dipetik Mei 27, 2018, dari eprints umsida: http://eprints.umsida.ac.id/1608/1/sitdew.pdf.

Roebyanto, G., \& Harmini, S. (2017). Pemecahan Masalah Matematika untuk $P G S D$. Bandung: PT Remaja Rosdakarya.

Ruseffendi, E.T. (2006). Pengantar Kepada Membantu Guru Mengembangkan Kompetensinya dalam Pengajaran Matematika untuk Meningkatkan CBSA. Bandung: Tarsito.

Sugiman, \& Kusumah, Y. S. (2010). Dampak Pendidikan Matematika Realistika Terhadap Peningkatan Kemampuan Pemecahan Masalah Siswa SMP. IndoMS J.M.E , 41-51.

Sugiyono. (2010). Memahami Penelitian Kualitatif. Bandung: Alfabeta.

Wahyudi, \& Anugraheni, I. (2017). Strategi Pemecahan Masalah Matematika. Salatiga: Satya Wacana University Press.

Wahyudi, \& Budiono, I. (2012). Pemecahan Masalah Matematika. Salatiga: Widya Sari Press.

Widodo, S. A., \& Sujadi, A. A. (2015). Analisis Kesalahan Mahasiswa dalam Memecahkan Masalah Trigonometri. Jurnal Sosiohumaniora, 51-63.

https://ojs.stkippgri-lubuklinggau.ac.id/index.php/JMSE 